\title{
Klinik Örneklerden Soyutlanan Anaerop Bakterilerin In Vitro Antibiyotik Duyarlılıkları
}

\section{In Vitro Antibiotic Susceptibilities of Anaerobic Bacteria Isolated from Clinical Samples}

\author{
Nida ÖZCAN'(iD), Neriman SAAT²(iD), Selahattin ATMACA'(iD)
}

'Dicle Üniversitesi Tıp Fakültesi, Tıbbi Mikrobiyoloji Anabilim Dalı, Diyarbakır, Türkiye
2 Samsun Halk Sag̃lığı Laboratuvarı, Klinik Mikrobiyoloji Bölümü, Samsun, Türkiye

* Bu çalıșmanın bir bölümü, 38. Türk Mikrobiyoloji Kongresi (4-8 Kasım 2018, Antalya)'nde sözlü bildiri olarak sunulmuștur.

\section{ÖZ}

Giriş: Insan ağız, gastrointestinal sistem, genitoüriner sistem ve cilt mikrobiyotasının önemli bir bölümünü oluşturan anaerop bakteriler, ekzojen veya endojen kaynaklı ciddi infeksiyonlara neden olabilir. Anaerop infeksiyonların örneklenmesi, ekimi ve inkübasyonu özel koşullar gerektirir. izole edilen anaerop bakterilerin geleneksel yöntemlerle tanımlanması da emek yoğun ve zaman alıcıdır. Mikrobiyolojik tanı ve direnç testlerinin uzun sürede sonuçlanması anaerop infeksiyonlarda ampirik antibiyotik tedavisini gerekli kılar. Ampirik tedavilere yol göstermesi açısından anaerop bakterilerin bölgesel duyarlılı profillerinin saptanması ve belirli periyodlarla izlenmesi çok önemlidir. Bu çalışma ile, laboratuvarımıza gönderilen çeşitli klinik örneklerden izole edilen anaerop mikroorganizmaların matriks aracılı lazer desorpsiyon/iyonizasyon-uçuş zamanı kütle spektrometresi (MALDI-TOF MS) ile tanımlanması ve bu mikroorganizmaların antimikrobiyal direnç profillerinin gradiyent test yöntemiyle belirlenmesi amaçlanmıştır.

Materyal ve Metod: Çalışmaya, Nisan 2017-Nisan 2018 tarihleri arasında anaerop kültür istemiyle gönderilen 368 klinik örnek dahil edildi. Örnekler anaerop kültür teknikleri kullanılarak inkübe edildi ve elde edilen izolatlar MALDI-TOF kütle spektrometresi ve fenotipik yöntemlerle tanımlandı. İolatların kloramfenikol, metronidazol, penisilin G, imipenem ve sefoksitine karşı antimikrobiyal direnci gradiyent test yöntemiyle belirlendi.

Bulgular: Örneklerin 73 (\%19.8)'ünden toplam 104 anaerop bakteri izole edilmiş; en sık soyutlanan etkenler, sırasıyla Bacteroides $(n=16)$, Actinomyces $(n=15)$, Prevotella $(n=12)$, Cutibacterium $(n=12)$ ve Peptoniphilus $(n=8)$ türleri olarak tespit edilmiştir. Toplam 65 izolata antibiyotik direnç testi çalışılmıştır. Gram-pozitif kokların \%61.1'i, gram-negatif bakterilerin \%33.3'ü metronidazole dirençli bulunmuştur. Gram-pozitif basillerin yaklaşık \%15.4'ü, gram-negatif basillerin ise yaklaşık \%14.3'ü sefoksitin ve imipeneme karşı dirençli bulunmuştur. Sefoksitin ve imipenem direnç oranları gram-pozitif koklarda \%11.1 ve \%22.2 olarak saptanmıştır.

Sonuç: Çalışma, bölgemizde saptanan anaerop bakterilere dair verilerin sunulduğu ilk çalışmadır. Metronidazol ve imipeneme direncin yüksek olması, ayaktan hastalarda metronidazol, hastanede yatan hastalarda ise karbapenem kullanımının yüksek olmasıyla ilişkili olabilir. Bölgesel antibiyotik duyarlılıklarının saptanması ampirik tedavileri yönlendirmenin yanı sıra akılcı antibiyotik kullanım politikalarının geliştirilmesinde de önemli rol oynar.

Anahtar Kelimeler: Bacteroides; Actinomyces; Prevotella; Antibiyotik direnci

Geliș Tarihi/Received: 27/07/2019- Kabul Ediliș Tarihi/Accepted: 03/03/2020

${ }^{\oplus}$ Telif Haklı 2020 Flora. Makale metnine www.floradergisi.org web adresinden ulașılabilir 


\title{
ABSTRACT \\ In Vitro Antibiotic Susceptibilities of Anaerobic Bacteria Isolated from Clinical Samples
}

\author{
Nida ÖZCAN', Neriman SAAT ${ }^{2}$, Selahattin ATMACA ${ }^{1}$
}

${ }^{1}$ Department of Medical Microbiology, Faculty of Medicine, University of Dicle, Diyarbakir, Turkey
2 Department of Clinical Microbiology, Samsun Public Health Laboratory, Samsun, Turkey

Introduction: Anaerobic bacteria, which constitute a significant part of human mouth, gastrointestinal tract, genitourinary system and skin microbiota can cause serious infections of exogenous or endogenous origin. Sampling, cultivation and incubation of anaerobic infections require special conditions. Empirical antibiotic therapy is frequently preferred for anaerobic bacterial infections due to long lasting microbiological diagnosis. Periodic monitoring of regional resistance data is essential to guide empirical treatments. In this study, it was aimed to identify anaerobic microorganisms isolated from various clinical samples sent to our laboratory by matrix-assisted laser desorption/ionization time-of-flight, mass spectrometry (MALDI-TOF MS) and to determine the antimicrobial resistance profiles of these microorganisms by gradient-test method.

Materials and Methods: The study included 368 clinical specimens sent for anaerobic culture between April 2017 and April 2018. Samples were incubated using anaerobic culture techniques and the isolates obtained were identified by MALDI-TOF mass spectrometry and phenotypic methods. Antimicrobial resistances of the isolates against chloramphenicol, metronidazole, penicillin $G$, imipenem and cefoxitin were determined by gradient test method.

Results: A total of 104 anaerobic bacteria were isolated from 73 (19.8\%) samples; the most frequently isolated anaerobic bacteria were Bacteroides ( $n=16)$, Actinomyces ( $n=15)$, Prevotella $(n=12)$, Cutibacterium $(n=12)$ and Peptoniphilus $(n=8)$ species. Antibiotic susceptibility testing was performed for 65 isolates. Metronidazole resistance among gram-positive bacilli, gram-positive cocci and gram-negative bacteria was found as $96.2 \%, 61.1 \%$ and $33.3 \%$, respectively. About $15.4 \%$ of gram-positive bacilli and $14.3 \%$ of gram-negative bacilli were resistant against both cefoxitin and imipenem. Among gram-positive cocci, cefoxitin and imipenem resistance rates were found as $11.1 \%$ and $22.2 \%$, respectively.

Conclusion: This is the first study to present data on anaerobic bacteria detected in our region. High resistance to metronidazole and imipenem may be associated with increased use of metronidazole in outpatients and carbapenem in hospitalized patients. Determination of regional antibiotic susceptibility plays an important role in developing rational antibiotic use policies as well as guiding empirical treatments.

Key Words: Bacteroides; Actinomyces; Prevotella; Antibiotic resistance

\section{GíRiș}

Toprakta, deniz, göl ve bataklıklarda yaygın olarak görülen anaerop bakteriler insanda ağız, gastrointestinal sistem, genitoüriner sistem ve deri mikrobiyotasının önemli kısmını olusturur. Anaerop bakteriler, ekzojen veya endojen kaynaklı infeksiyonlara neden olabilir ${ }^{[1]}$. Bu infeksiyonların tanısında örnek alımı, tașınması, kültürü ve izolasyonu özel koșullar gerektirir. Kültür için kullanılacak özel besiyerleri, anaerop atmosfer kosullar1nın sağlanması ve uzatılmıs inkübasyon, anaerop bakteri izolasyonunun en önemli bileșenleridir ${ }^{[2]}$. Anaerop bakterinin izolasyon sonrası geleneksel yöntemlerle tanımlama süreci de emek yoğun ve zaman alıcıdır. Saflaștırma subkültürleri ve sonrasında tanımlayıcı antibiyotik disklerine karș1 duyarlllık saptanmasını gerektirir ${ }^{[1]}$. Son yıllarda rutin mikrobiyoloji laboratuvarlarında kullanılmaya bașlanan matriks aracilı lazer dezorpsiyon/iyonizasyon-uçus zamanı kütle spektrometresi [Matrix Assisted Laser Desorption/Ionization-Time of Flight Mass Spectrometry (MALDI-TOF MS)] anaerop bakterilerin tanımlanmasında önemli ölçüde zaman ve emek tasarrufu sağlamaktadır. Kütle spektrometre yöntemiyle, kültürde üreyen anaerop bakterilerin \%70'den fazlasının cins ve tür düzeyinde doğru tanımlanabildiği bildirilmiștir ${ }^{[3-5]}$. Ülkemizde yürütülen cok merkezli bir calıșmada Ülger Toprak ve arkadașları, Prevotella cinsine ait 508 izolatın tanımlanmasında kütle spektrometreyi $16 \mathrm{~S}$ rRNA yöntemiyle karșlaștırmıș; kütle spektrometre ile izolatların \%90.4'ünün cins düzeyinde, \%83.1'inin ise tür düzeyinde doğru tanımland1ğını belirtmișlerdir ${ }^{[6]}$. 
Anaerop bakteri infeksiyonlarının büyük kısmı polimikrobiyaldir ve coğunlukla duyarlllik testine gerek duyulmadan ampirik tedavi baslanir. Amerika kaynaklı "Clinical and Laboratory Standard Institute (CLSI)" klavuzu, polimikrobiyal anaerop infeksiyonlarda duyarlllık testi gerektiğinde en dirençli izolat için test yapılmasını önermekte$\operatorname{dir}^{[7]}$. Gerek CLSI, gerekse Aurupa Antimikrobiyal Duyarll1.k Testler Komitesi (EUCAST), anaerop bakterilerin antibiyotik duyarlllkklarının minimum inhibitör konsantrasyonu (MiK) temelli testlerle calıṣlmasını önerir ${ }^{[7-9]}$. Altın standart yöntem olan agar dilüsyon yöntemi emek-yoğun bir calıșma gerektirdiğinden rutin laboratuvarlarda tercih edilmez, genellikle referans laboratuvarlarda kullanilir. Katı besiyerinde difüzyon yoluyla MiK saptayabilen gradiyent test yöntemi, agar ve sivı dilüsyon yöntemlerine kıyasla kolay uygulanabilir bir yöntem olduğundan anaerop bakterilerin duyarlllık tespitinde rutin laboratuvarlarda en sik tercih edilen yöntemdir.

Anaerop bakteri infeksiyonlarında kullanilabilecek antibiyotikler sınırl sayıdadır. Amoksisilin-klavulanik asit, ampisilin-sulbaktam, piperasilin-tazobaktam, klindamisin, imipenem, meropenem, doripenem, ertapenem ve metronidazol, CLSI dokümanlarında gram-pozitif ve gram-negatif anaerop bakteriler için öncelikli test edilecek ve raporlanacak antibiyotiklerdir. Gerektiğinde calıșlıp kısıtlı bildirilmesi gereken antibiyotikler ise sefoksitin, sefotetan, seftizoksim, seftriakson, kloramfenikol, moksifloksasin ve tetrasiklin olarak belirlenmistir. Penisilin ve ampisilin gram-pozitif bakterilerde öncelikli test edilmesi gereken grupta, gram-negatif bakterilerde ise kısitlı bildirilmesi gereken grupta yer alır ${ }^{[7]}$. CLSI verilerinden farklı olarak EUCAST dokümanlarında, ampisilin, amoksisilin ve piperasilinin beta-laktamaz inhibitörü içermeyen formlarıyla beraber tikarsilin ve tikarsilin-klavulanik asit için de MiK sınır değerleri belirtilmiștir. EUCAST'ın güncel dokümanlarında anaerop bakterilere etkili antibiyotik listesinde doripenem yer almazken, sefoksitin ve tetrasiklin için MiK sınır değerleri belirtilmemektedir ${ }^{[8]}$.

Anaerop bakterilerde son dekadlarda artan antibiyotik direnci anaerop bakteri infeksiyonlarında ampirik tedavi seçeneklerinin öngörülmesini zorlaștırmaktadır $^{[10-12]}$. Farklı ülke ve bölgelerden anaerop bakterilere dair farkl duyarlılı profilleri bildirilmektedir. Amerika ve Aurupa'dan 19902010 yılları arasında anaerop bakterilerle ilgili yayınların irdelendiği bir calıșmada, antibiyotiklere göre değismekle beraber antibiyotik direncinin genel olarak artma eğiliminde olduğu bildirilmiștir ${ }^{[13]}$. Ülger Toprak ve arkadașlarının yürüttuuğü, Avrupa'nın farklı bölgelerini de içeren çok merkezli bir calısmada Prevotella cinsine ait toplam 508 izolatta meropenem, imipenem, tigesiklin, piperasilin/ tazobaktam ve metronidazole direnc saptanmazken ampisilin, tetrasiklin, klindamisin ve moksifloksasin direnc oranları sirasiyla \%51.2, \%36.8, \%33.7 ve \%18.3 olarak saptanmıstır ${ }^{[14]}$. Tayvan'da yapilan bir çalısmada ise klinik örneklerden sıklikla izole edilen anaerop bakterilerden Fusobacterium spp., Prevotella spp. ve Bacterioides fragilis grubu bakterilerde karbapenem direncinin son 10 yılda artıș gösterdiği bildirilmiștir ${ }^{[15]}$. Bakterilerdeki direnç genlerinin aktarılabilir özellik tassımas1 dirençli izolatların yayılımı konusunda dikkatli olmay1 gerektirmektedir ${ }^{[16]}$. Anaerop bakterilerin direnc paternlerinin bölgesel ve periyodik izlemi anaerop bakteriyel infeksiyonların tedavi bașarısı için elzemdir.

$\mathrm{Bu}$ calısmada, laboratuvarımıza gönderilen cesitli klinik örneklerden izole edilen anaerop mikroorganizmaların MALDI-TOF MS ile tanımlanması ve bu mikroorganizmaların antimikrobiyal direnc profillerinin gradiyent test yöntemiyle belirlenmesi amaçlanmıștır.

\section{MATERYAL ve METOD}

Calıșma için Dicle Üniversitesi Tıp Fakültesi Girișimsel Olmayan Klinik Araștırmalar Etik Kurulu'ndan 16.12.2016 tarih ve 346 sayll karar ile onay alınd.

Calıșmaya, Nisan 2017-Nisan 2018 tarihleri arasında Dicle Üniversitesi Hastanesinin ceșitli kliniklerinden anaerop kültür istemiyle merkez laboratuvarı bakteriyoloji birimine gönderilen 368 klinik örnek dahil edildi. Anaerop kültür istemi yapılan örneklerin büyük kısmı steril enjektör içinde, büyük doku parçaları ise laboratuvarımızda hazırlanan tiyoglikolatlı sivı besiyerleri (TSB) (Oxoid, İngiltere) içerisinde dakikalar içerisinde laboratuvara ulaștırıldı. Örnekler makroskobik (örneklerin pürülan, kanlı olması, kötü koku ve sülfür gra- 
nülleri içermeleri gibi) değerlendirmeden hemen sonra \%5 defibrine koyun kanı eklenmis Brusella agar (Oxoid, İngiltere) besiyerine ekildi. Mikroskobik inceleme (lökosit varlığı, bakterilerin Gram boyanma ve morfolojik özellikleri, spor içerip içermemeleri) ile es zamanlı olarak aerop besiyerlerine de ekim yapıld. Enjektör içinde gelen örnekler ek olarak geri dönüș sıvısı için kullanılan TSB'ye birakildi ${ }^{[17]}$.

Anaerop ekim yapilan besiyerleri, anaerop ortam olușturucu paketler -AnaeroPack ${ }^{\mathrm{TM}}$ (Mitsubishi Gas Chemical, Japonya)- ile birlikte BD GasPak $^{\mathrm{TM}}$ EZ (Becton Dickinson, ABD) konteynır sistemlere birakıldı. Anaerop ortam kontrolü için resazurin emdirilmiș kağıt stripler -Anerotest (Oxoid, İngiltere)- konteynır içine yerleștirilerek striplerin 1-2 saat içinde maviden beyaza dönüștüğü gözlemlendi ${ }^{[18]}$.

Anaerop konteynir sistem ile aerop ekim yapilan besiyerleri $35-37^{\circ} \mathrm{C}$ 'de 48 saat inkübasyona bırakıldı. Inkübasyon sonrası aerop ve anaerop üremeler karșlaștırıldı. Üreme olmayan örneklerde anaerop inkübasyon bes güne uzatılarak, bulanıklık gözlenen tiyoglikolatlı besiyerlerinden tekrar ekimler yapild.

Besiyerinde üreyen etkenlerin tanımlanmasında koloninin makroskobik görünümü, mikroskobik morfoloji ve Gram boyanma özelliği dikkate alındı. Aerotolerans test için BKA ve cikolata agar besiyerine (RTA, Türkiye) es zamanl subkültürleri yaplan etkenlerden cikolata agar besiyerinde \%5-10 $\mathrm{CO}_{2}$ 'li ortamda üremeyip BKA besiyerinde üreyenler tanimlama diskleri ve kütle spektrometre ile tanımlandı. Antibiyotik tanı disk testi için kanami$\sin (1000 \mu \mathrm{g})$, kolistin $(10 \mu \mathrm{g})$, ve vankomisin (5 $\mu \mathrm{g})$ diskleri (Bioanalyse, Türkiye) kullanıldı ${ }^{[19]}$. Saf kültürlerden 0.5 McFarland bulanıklığında hazırlanan bakteri süspansiyonlarından BKA besiyerine homojen ekim yapild. Her besiyerine kolistin, kanamisin ve vankomisin disklerinden birer adet bırakıldı, 48 saatlik anaerop inkübasyon sonrası disklere duyarlilık durumlarına göre bakteri cinsine karar verildi ${ }^{[1,18,19]}$.

Kütle spektrometre ile tanımlanma için besiyerinde üreyen koloni, ekstraksiyon ișlemi uygulanmaksızın celik plak üzerindeki dairesel alanlara sürüldü. Kuruyan örneklerin üzerine sırasıyla formik asit ve Bruker matriks çözeltisi (Bruker HCCA: $\alpha$-Cyano-4-hydroxycinnamic acid) eklendi, ardından celik plak Microflex LT (Bruker Daltonics, Almanya) cihazına bırakılarak 2-20 kDa kütle aralığında, pozitif lineer modda lazer atıșları uyguland1. İyonizasyon sonucu elde edilen spektrum görüntüleri Maldi Biotyper 3.1 (Bruker Daltonics, Almanya) sisteminin veri tabanındaki spektrumlarla karșlaștırılarak analiz edildi. Cins düzeyinde tanımlama için 1.7 'den yüksek skorlar, tür düzeyinde tanımlama için ise 2'den yüksek skorlar kabul edildi ${ }^{[20]}$.

İzolatların antimikrobiyal direncini belirlemek için kloramfenikol, metronidazol, penisilin G, imipenem ve sefoksitin gradiyent test stripleri (Liofilchem, Italy) kullanıldı. Antibiyotik duyarlılık testi (ADT) için üretici firma önerisi doğrultusunda 0.5 McFarland bulanıklığındaki bakteri süspansiyonunun homojen yayıldığı BKA besiyerlerine gradiyent test stripleri yerlestirildi. CLSI, anaerop bakteri ADT'si için en ideal katı besiyeri olarak koyun kanı yanı sira vitamin $\mathrm{K}$ ve hemin ilave edilmiş Brusella agar besiyerini önermekle birlikte BKA veya Wilkins Chalgren agarda elde edilen MiK değerlerini de eșdeğer saymaktadır ${ }^{[7]}$. İnkübasyon sonrası elde edilen MIK değerleri, sefoksitin için CLSI, diğer antibiyotikler için EUCAST Version 8.0 kriterlerine göre yorumlandi ${ }^{[8,21]}$. Her ADT calıșması sırasında B. fragilis ATCC 25285 standart izolatı da test edilerek kalite kontrol uyguland1.

\section{BULGULAR}

Calıșmaya alınan 368 örneğin 229 (\%62.2)'unu apse, 52 (\%14.1)'sini doku, 38 (\%10.3)'ini eklem sivisı, 25 (\%6.8)'ini plevra, 16 (\%4.3)'sını periton sivisı, 8 (\%2.2)'ini cerrahi operasyon s1rasında alınan kulak örnekleri olușturmuștur. Anaerop bakteriler örneklerin 73 (\%19.8)'ünden izole edilmiș; bu örneklerin 50 (\%13.6)'sinde sadece anaerop etkenler, 23 (\%6.3)'ünde ise anaerop bakterilerin yanı sıra aerop/fakültatif anaerop etkenler de üretilmiștir. Anaerop üreme saptanan 73 örnekten toplam 104 adet anaerop bakteri soyutlanmıs; her bir anaerop üreme bașına ortalama 1.5 adet anaerop bakteri üremesi olmustur. Anaerop bakterilerin büyük kısmı $(n=52)$ apse örneklerinden izole edilirken; doku, eklem, plevra, kulak ve periton örneklerinden sirasıyla 24, 12, 
Tablo 1. Anaerop kültür istemi ile gelen örnek türleri ve üreme durumları

\begin{tabular}{|c|c|c|c|c|c|c|c|}
\hline Örnek türü & Apse & Doku & Eklem sıvısı & Plevra sıvısı & $\begin{array}{l}\text { Periton } \\
\text { sIVISI }\end{array}$ & Kulak & Toplam \\
\hline Örnek n (\%) & $229(62.2)$ & $52(14.1)$ & $38(10.3)$ & $25(6.8)$ & $16(4.4)$ & $8(2.2)$ & $368(100)$ \\
\hline $\begin{array}{l}\text { Tek başına anaerop üreme } \\
(\mathrm{n})\end{array}$ & 22 & 16 & 7 & 3 & 1 & 1 & $50(13.6)$ \\
\hline $\begin{array}{l}\text { Karışık (anaerop ve diğer*) } \\
\text { üreme }(n)\end{array}$ & 9 & 3 & 2 & 4 & 2 & 3 & $23(6.3)$ \\
\hline Diğer* üreme (n) & 83 & 1 & 1 & 2 & 0 & 1 & $88(23.9)$ \\
\hline Üreme yok (n) & 115 & 32 & 28 & 16 & 13 & 3 & $207(56.2)$ \\
\hline $\begin{array}{l}\text { Üreyen anaerop } \\
\text { mikroorganizma }(n)\end{array}$ & 52 & 24 & 12 & 11 & 5 & 8 & 104 \\
\hline
\end{tabular}

11, 8 ve 5 anaerop bakteri izole edilmiștir (Tablo 1). Klinik örneklerden en sık $(n=16)$ soyutlanan Bacteroides izolatlarının 10'u B. fragilis, ikisi ise Bacteroides thetaiotaomicron olarak tür düzeyinde, dört izolat ise cins düzeyinde tanımlanmıstır. Bacteroides türleri en fazla karın içi $(\mathrm{n}=6)$ ve perianal $(\mathrm{n}=4)$ bölgelerden izole edilmiștir. Actinomyces, Prevotella, Cutibacterium ve Peptoniphilus türlerinden sirasiyla $15,12,12$ ve 8 izolat tanımlanmıstır. Toplam 15 Actinomyces izolatı kütle spektrometre ile Actinomyces odontolyticus $(\mathrm{n}=4)$, Actinomyces oris $(\mathrm{n}=3)$, Actinomyces radingaee $(\mathrm{n}=3)$, Actinomyces europeaus $(\mathrm{n}=1)$, Actinomyces schaalii $(\mathrm{n}=1)$ ve Actinomyces spp. $(\mathrm{n}=3)$ olarak tanımlanmıștır. Actinomyces türleri en fazla bas-boyun ve cilt apselerinden izole edilmiștir. Prevotella spp., Bacteroides cinsinden sonra en sik izole edilen gram-negatif anaerop bakteriler olup en fazla bas-boyun, eklem ve kulak örneklerinden izole edilmiștir. Bir bașka gram-negatif etken olan Fusobacterium spp. izolatlarının ikisi karın içi, ikisi ağız içi lezyonlardan, biri de bas-boyun bölgesinden izole edilmiștir. Bakteriyel vajinoz etkenlerinden olan Mobilincus spp. izolatlarının ikisi de vulva ve vajen örneklerinde saptanmıstır. Tanımlanan anaerop bakterilerin izole edildikleri vücut bölgelerine göre dağılımı Tablo 2'de özetlenmiștir.

Tanımlanan 104 anaerop bakteriden 39'u subkültür ișlemleri sırasında üretilememiștir.

ADT calıșlan toplam 65 izolatın 26 (\%40)'sını gram-pozitif basiller, 18 (\%27.7)'ini gram-pozitif koklar, 21 (\%32.3)'ini de gram-negatif bakteriler (20 basil, 1 kok) olușturmuștur. Anaerop bakteriyel infeksiyonlarda sıklikla kullanilan metronidazole gram-pozitif koklarda \%61.1, gram-negatif bakterilerde \%33.3 oranında direnç saptanmıștır. Gram-negatif basillerin \%76.2'si, gram-pozitif kokların \%50'si ve gram-pozitif basillerin \%30.8'i penisiline dirençli bulunmuștur. Kloramfenikole direnc gram-negatif basillerin \%42.9'unda, gram-pozitif basillerin \%19.2'sinde, gram-pozitif koklarm ise \%16.7'sinde tespit edilmistir. Gradiyent test calıșlan bes antibiyotikten en düșük oranda direnc saptananlar sefoksitin ve imipenem olmustur. Her iki antibiyotiğe karșı gram-pozitif basillerin \%15.4 (4/26)'ü, gram-negatif basillerin ise \%14.3 (3/21)'ü direncliyken; gram-pozitif koklarda sefoksitine direnc \%11.1 (2/18), imipeneme direnc ise \%22.2 (4/18) olarak belirlenmiștir. İmipeneme dirençli 11 izolatın altısı calıșmadaki tüm antibiyotiklere; beși ise diğer antibiyotiklerin en az ikisine dirençli bulunmuștur (Tablo 3).

\section{TARTIȘMA}

Anaerop bakteriler normal insan vücut florasının önemli üyeleri olup gastrointestinal sistem, kadın genital sistemi, deri ve ağız bașta olmak üzere, vücudun pek cok bölgesinde yer alır. Bağısıklı sisteminin zayiflaması ve vücudun anatomik bütünlüğünün zarar görmesi sonucunda, mortalite ve morbiditesi yüksek anaerop infeksiyonlar görülebilmektedir ${ }^{[1]}$. Antibiyotik direnci dünya capinda hızla artarken, farklı coğrafyalardan dirençli anaerop bakteriler de bildirilmektedir ${ }^{[10,11,15,22]}$. 


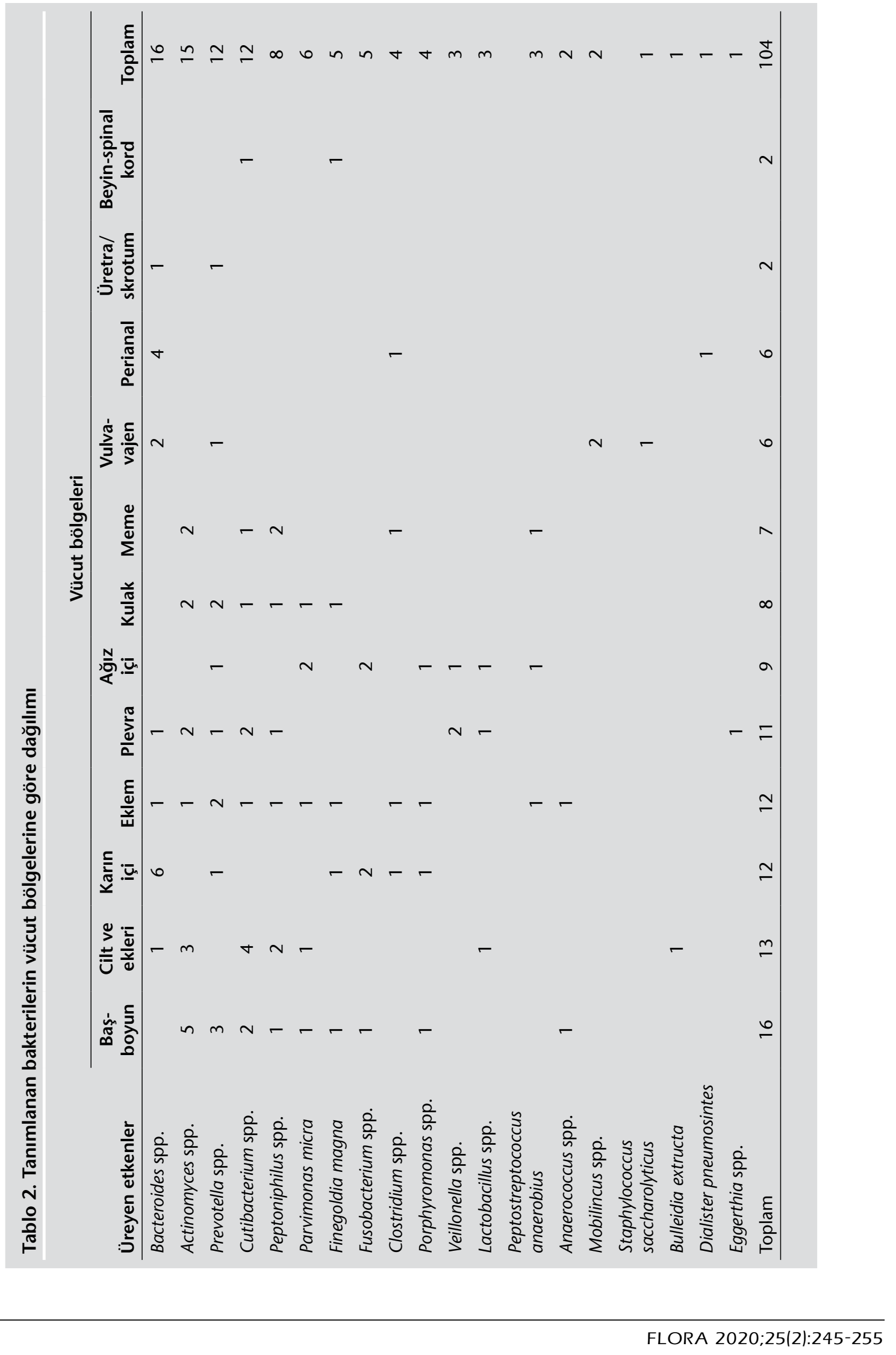


Tablo 3. İzole edilen anaerop bakterilerin antibiyotiklere direnç durumları

\begin{tabular}{|c|c|c|c|c|c|c|c|}
\hline & \multirow[b]{2}{*}{ Bakteri adı } & \multirow[b]{2}{*}{ n (\%) } & \multicolumn{5}{|c|}{ Antibiyotiklere dirençli bakteri (n) } \\
\hline & & & IMI & MTR & FOX & C & $\mathbf{P}$ \\
\hline \multirow{6}{*}{ 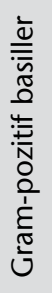 } & Cutibacterium spp. & 10 & 1 & 10 & 0 & 2 & 1 \\
\hline & Actinomyces spp. & 10 & 1 & 10 & 1 & 1 & 2 \\
\hline & Lactobacillus spp. & 3 & 2 & 3 & 2 & 1 & 1 \\
\hline & Eggerthia spp. & 2 & 0 & 2 & 0 & 1 & 2 \\
\hline & Bulleidia extructa & 1 & 0 & 0 & 1 & 0 & 1 \\
\hline & Toplam n (\%) & $26(100)$ & $4(15.4)$ & $25(96.2)$ & $4(15.4)$ & $5(19.2)$ & $8(30.8)$ \\
\hline \multirow{7}{*}{ 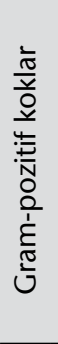 } & Peptoniphilus spp & 5 & 2 & 3 & 2 & 1 & 4 \\
\hline & Peptostreptococcus anaerobius & 1 & 0 & 1 & 0 & 0 & 1 \\
\hline & Anaerococcus spp. & 5 & 1 & 4 & 0 & 0 & 2 \\
\hline & Finegoldia magna & 3 & 1 & 2 & 0 & 2 & 2 \\
\hline & Parvimonas micra & 3 & 0 & 0 & 0 & 0 & 0 \\
\hline & Staphylococcus saccharolyticus & 1 & 0 & 1 & 0 & 0 & 0 \\
\hline & Toplam n (\%) & $18(100)$ & $4(22.2)$ & $11(61.1)$ & $2(11.1)$ & $3(16.7)$ & $9(50)$ \\
\hline \multirow{10}{*}{ 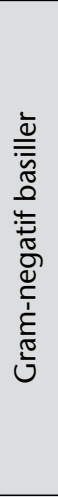 } & Bacteroides fragilis & 6 & 1 & 2 & 2 & 4 & 6 \\
\hline & Bacteroides thetaiotaomicron & 1 & 0 & 0 & 0 & 0 & 0 \\
\hline & Prevotella spp. & 6 & 0 & 0 & 0 & 2 & 5 \\
\hline & Porphyromonas spp. & 2 & 1 & 1 & 1 & 1 & 1 \\
\hline & Fusobacterium necrophorum & 2 & 0 & 1 & 0 & 0 & 0 \\
\hline & Fusobacterium nucleatum & 1 & 0 & 1 & 0 & 0 & 1 \\
\hline & Dialister pneumosintes & 1 & 0 & 1 & 0 & 0 & 1 \\
\hline & Mobilincus spp. & 1 & 1 & 1 & 0 & 1 & 1 \\
\hline & Veillonella parvula* & 1 & 0 & 0 & 0 & 1 & 1 \\
\hline & Toplam & $21(100)$ & $3(14.3)$ & $7(33.3)$ & $3(14.3)$ & $9(42.9)$ & $16(76.2)$ \\
\hline \multicolumn{2}{|c|}{ Genel Toplam } & 65 & $11(16.9)$ & $43(66.2)$ & $9(13.8)$ & $17(26.2)$ & $33(50.8)$ \\
\hline
\end{tabular}

Çalıșmamızda anaerop bakteriler 368 klinik örneğin 73 (\%19.8)'ünden izole edilmis; bu örneklerin 50 (\%13.6)'sinde sadece anaerop, 23 (\%6.3)'ünde ise anaerop bakterilerin yanı sira aerop/fakültatif anaerop etkenler soyutlanmıștır. Ülkemizde anaerop bakterilere dair yapilan az sayıda çalıșmada farklı oranlarda anaerop bakteri üremeleri saptanmıstır. Ankara'da 1999-2004 yılları arasında yapılan bir calıșmada 394 klinik örneğin 75 (\%20.5)'inde aerop ve anaerop etkenler birlikte, 28 (\%7.6)'inde ise tek bașina anaerop bakteriler izole edilmistir ${ }^{[23]}$. Erzurum'da 2000 y1lına ait bir calıșmada 100 klinik örnekten 40'ında birer anaerop izolat soyutlanmıștır ${ }^{[24]}$. Bozkurt ve arkadașlarının 2002 yılında yaptıkları 238 klinik örneğin dahil edildiği çalıșmada, 39 (\%16.4) anaerop izolat patojen olarak değerlendirilmiștir ${ }^{[25]}$. Demir ve Keșli, bir ylllı zaman diliminde 278 klinik örnekten 28 anaerop bakteri soyutlamıslardır ${ }^{[26]}$. Doğan ve Baysal, Konya'da 2007 yilında yaptıkları bir calıșmada 100 klinik örneğin sekizinde anaerop ve fakültatif anaerop, yedisinde çoklu anaerop bakteri ürediğini bildirmișlerdir ${ }^{[27]}$. Uysal ve arkadaslarının Cumhuriyet Üniversitesinin yedi yıllık verilerini inceledikleri bir calısmada 543 örneğin 134 (\%24.6)'ünde anaerop bakteri soyutlanmıștır ${ }^{[28]}$. Eskișehir Osmangazi Üniversitesinde 2007-2008 yılları arasında yürütülen bir tez calıșmasında 14 aylık bir süre içinde 241 klinik örneğin 31 (\%12.9)'inden anaerop etkenler, 
17 (\%7)'sinden anaerop ve aerop etkenler izole edilmiștir $^{[29]}$. Parapnömonik efüzyonu olan 236 hastanın 66 (27.9\%)'sında plevral sıvı örneklerinde anaerop bakteriler soyutlanmıstır ${ }^{[30]}$.

Bacteroides (16/104), Actinomyces (15/104), Prevotella (12/104), Cutibacterium (12/104) ve Peptoniphilus (8/104) cinsleri calıșmamızda en fazla soyutlanan anaerop bakterilerdi. Uysal ve arkadașlarının calıșmasında Bacteroides spp. (\%29.9), Peptopstreptococcus spp. (\%23.1) ve Cutibacterium spp. (\%20.2) en fazla izole edilen anaerop bakteriler olarak bildirilmistir ${ }^{[28]}$. Slovenya'da ücüncü basamak bir hastanede izole edilen 2673 anaerop bakteri MALDI-TOF MS yöntemi ile tanımlanmıs; $B$. fragilis grubu $(n=817, \% 31)$, gram-pozitif koklar ( $\mathrm{n}=589, \% 22)$, Prevotella spp. $(\mathrm{n}=313, \% 14)$ ve Cutibacterium spp. $(\mathrm{n}=$ 225, \%8) en sik saptanan bakteriler olarak bildirilmiștir $^{[2]}$. Demir ve Keșli'nin 278 klinik örneği dahil ettikleri calıșmada 28 anaerop gram-negatif basilin 14 'ü $B$. fragilis grup, dokuzu Prevotella spp., beși de Fusobacterium spp. olarak tanımlanmıștır ${ }^{[26]}$. Kesli ve Celebi'nin 100 klinik örnekten izole ettikleri 40 anaerop bakterinin $11^{\prime} \mathrm{i} B$. fragilis grup, beși gram-pozitif sporlu basil, ikisi Fusobacterium spp. olarak bildirilmiștir ${ }^{[24]}$. Bozkurt ve arkadaşlarının 2002 yılında 238 klinik örneğin dahil edildiği çalıșmalarında Actinomyces israelii (14/39) ve Cutibacterium acnes (9/39) en sik saptanan etkenler olarak bildirilmiștir ${ }^{[25]}$. Eskișehir'de Argun Türkkan ve Kiremitçi'nin tez calıșmasında en fazla izole edilen anaerop etkenler Bacteroides spp. (14/54), Porphyromonas spp. (10/54) ve Peptostreptococcus spp. (10/54) olarak bildirilmistir ${ }^{[29]}$. Ampiyem örneklerinin incelendiği calıșmada ise en sık soyutlanan anaerop bakteriler Peptostreptococcus spp. ( $n=41$, $\% 34.8), B$. fragilis $(n=28, \% 23.7), P$. acnes $(\mathrm{n}=17, \% 14.4)$ ve $P$. melaninogenica $(\mathrm{n}=8$, \%6.8) olarak bildirilmiștir [30]. Rusya'da bir kanser araștırma merkezinde gram-pozitif anaerop kokların incelendiği bir çalıșmada toplam 81 izolatın büyük kısmını Finegoldia magna ( $\mathrm{n}=38$, \%47) ve Peptoniphilus harei $(\mathrm{n}=23, \% 28)$ izolatlarının olușturduğu; diğer izolatların Parvimonas micra ( $n=8)$, Peptostreptococcus anaerobeus $(n=7)$, Anaeroccoccus vaginalis $(\mathrm{n}=4)$ ve Peptoniphilus gorbachii $(n=1)$ olduğu bildirilmiștir ${ }^{[31]}$.
Calıșmamızda ADT çalıșlan gram-pozitif basillerin neredeyse tamamı (25/29) metronidazole dirençli bulunmuștur. Bu durum Actinomyces, Cutibacterium, Bifidobacterium ve Lactobacillus türleri bașta olmak üzere spor olușturmayan gram-pozitif anaerop basillerin coğunda bulunan intrensek direncin göstergesidir ${ }^{[7]}$.

Calıșmamızda gram-pozitif kokların yarıdan fazlası (11/18), gram-negatif bakterilerin ise üçte biri (7/21) metronidazole dirençli bulunmuștur. Anaerop bakterilerle ilgili oldukça geniș bir derlemede, gerek Avrupa gerekse Amerika'da gram-pozitif kok ve gram-negatif basillerde metronidazol direncinin oldukça düșük $(<\% 1)$ olduğu bildirilmiștir $^{[13]}$. Ülkemizden bildirilen oranlar ise değișkenlik göstermektedir. Van'da 39 anaerop (26'sı gram-pozitif basil) izolatın dahil edildiği çalıșmada metronidazole direnç \%94.9 ile en yüksek oranda bildirilirken aynı calıșmada klindamisin, karbenisilin, sefotaksim, tetrasiklin, sefoksitin ve kloramfenikole direnc oranları sirasiyla \%56.4, \%48.7, \%38.4, \%35.9, \%33.3 ve \%12.8 olarak saptanmıstır ${ }^{[25]}$. Konya'da 22 izolat ile yaplan bir çalısmada gram-pozitif koklarda metronidazol direnci bildirilmezken, 12 gram-negatif basilin 1 (\%8.3)'inde, üc gram-pozitif basilin ikisinde metronidazole direnç saptanmıstır ${ }^{[27]}$. Afyon'da 28 anaerop izolatın test edildiği calıșmada tüm izolatların metronidazole duyarlı olduğu bildirilmiștir $^{[26]}$. 2010-2016 yılları arasında dokuz Avrupa ülkesinden 7008 anaerop izolatın dahil edildiği bir sürveyans çalısmasında gram-pozitif ve gram- negatif izolatlar arasında en düșük direncin meropenem ve metronidazole karșı olduğu belirtilmiștir (sırasıyla \%0-1.7 ve \%0-1.9) ${ }^{[32]}$. Wybo ve arkadașları 2012 yılında yürüttükleri bir çalıșmada, 403 anaerop izolatın \%8'inin metronidazole dirençli olduğunu bildirmișlerdir ${ }^{[33]}$. Metronidazole direnc, Avrupa'da cok düșük, ülkemizin diğer bölgelerinde ise düsüuk oranlarda bildirilirken, Van ve Diyarbakır'da saptanan yüksek oranlar dikkat cekmektedir. Antibiyotik direnc profilleri ülkelere, bölgelere hatta hastanelere göre değișkenlik gösterebilir. Belirli antibiyotiklerin yüksek oranda kullanımı dirençli izolatların seleksiyonuna ve yayılımına yol açabilir. Calıșmamızda saptanan yüksek metronidazol direncinin, bölgemizde antibiyotiğin yüksek oranda irrasyonel kullanımına bağlı olabileceğini düșünmekteyiz. Giardiyaz gibi 
bağırsak paraziter hastalıklarının sık görüldüğu bu bölgelerde akut gastroenterit tedavisinde ampirik metronidazol kullanım oranının yüksek olması metronidazol direncine katkı sağlamıș olabilir. Anaerop infeksiyonların tedavisinde sıklıkla kullanilan metronidazole bu düzeyde direnç gelișmesi endișe vericidir. Akılcı antibiyotik kullanımının önemini gösteren bu veriler metronidazolün endikasyon dıșı kullanımlarının azaltılmasına yönelik ciddi önlemler alınmasını gerekli kılar.

ADT calıștığımız gram-pozitif basillerin \%30.8'inde, gram-pozitif kokların \%50'sinde, gram-negatif bakterilerin ise \%76'sında penisilin G'ye direnç saptanmıștır. Kloramfenikol direnci gram-negatif basillerde \%42.9 iken gram-pozitif basil ve koklarda nispeten daha düșik oranlarda (sırasıyla \%19.2 ve \%16.7) bulunmustur. İmipenem ve sefoksitine direnc, sirasıyla \%16.9 ve $\% 13.8$ ile düsük oranlarda saptanmıs ancak özellikle imipeneme direncin literatür verilerine göre yüksekliği dikkat cekmiștir. Belçika'da 2012 yılında, 403 anaerop izolatın dahil edildiği bir çalıșmada EUCAST sınır değerleri dikkate alındığında izolatların \%60'ının penisiline, \%30'unun klindamisine dirençli olduğu; piperasilin-tazobaktam, amoksisilin-klavulanik asit, meropenem ve kloramfenikole direncin ise sırasıyla \%9, \%6, \%4 ve $\% 2$ olduğu bildirilmiștir ${ }^{[33]}$. Ülger Toprak ve arkadașlarının Bacteroides cinsine ait bakterilerde karbapenem direnciyle ilgili yayınında 66 izolatın \%27'sinde karbapenemaz metallo-beta-laktamaz geni olan cfiA geninin saptandığı, ancak 66 izolatın beșinde fenotipik olarak karbapenem direnci görüldüğui bildirilmiștir ${ }^{[34]}$. Son yıllarda karbapenem grubu antibiyotik kullanımı ve bunun getirisi olan karbapenem direncinin artmasinin anaerop bakterileri de etkilemesi kaçınılmazdır.

Doğan ve Baysal'ın 2010 yılına ait Konya'da yaptıkları calıșmada soyutlanan tüm izolatların imipenem ve piperasilin-tazobaktama duyarlı oldukları, 22 izolattan dokuzunun penisiline direncli olduğu, gram-pozitif kokların calıșılan tüm antibiyotiklere duyarlı oldukları saptanmıștır. Gram-negatif basillerde penisilin ve klindamisin direncleri sirasıyla \%75 (9/12) ve \%33.3 (4/12) olarak saptanırken toplam üc adet gram-pozitif basilden birer izolatın klindamisin ve sefoksitine dirençi olduğu belirtilmiștir ${ }^{[27]}$. Afyon'da 28 gram-negatif izolatın dahil edildiği calıșmada penisilin, sefoksitin ve klindamisine sirasıla \%78.5, \%21.4 ve \%17.8 direnç saptanırken moksifloksasin, imipenem, meropenem, ertapenem ve doripeneme direnç saptanmamıstır ${ }^{[26]}$.

Calıșmamızda dirençli izolat oranının görece yüksek olmasında calıșılan izolat sayısının azlığının etkisi olduğunu düșünmekteyiz. Bu çalıșma bölgemize ait anaerop etkenler ve antibiyotik direnç paternlerinin paylașılmasına dair bir bașlangıc niteliğinde olup daha cok sayıda izolatın dahil edildiği periyodik izlemlerle bu verilerin arttırılması umudunu tașımaktayız. Bölgesel direnç verileri ampirik tedavilere yol göstermenin yanı sıra akılc1 antibiyotik kullanımı ile ilgili önlemler konusunda da önemli veriler sağlar. Metronidazol ve imipeneme direncin yüksek olması, bölgemizde ayaktan hastalarda metronidazol, hastanede yatan hastalarda ise karbapenem kullanımının yeniden gözden gecirilmesini ve antibiyotikleri akılcı kullanmaya yönelik önlemlerin arttırılmasını gerekli kılacaktır.

Calıșmamızın bir diğer eksikliği, anaerop etkenlerin tanımlanmasında altın standart olan 16S rRNA sekanslama yönteminin kullanılamamıs olmasıdır. Gerek bakterilerin tiplendirilmesi gerekse dirençli izolatlarda dirence yol açan genlerin gösterilmesi açısından moleküler çalıșmalara ihtiyaç vardır.

$\mathrm{Bu}$ çalıșma, Dicle Úniversitesi Bilimsel Araștırma Proje Koordinatörlüğü (DÜBAP) tarafından TIP-17-01 no'lu proje ile desteklenmiștir.

\section{ETIK KURUL ONAYI}

Calıșma için Dicle Üniversitesi Tıp Fakültesi Girișimsel Olmayan Klinik Araștırmalar Etik Kurulu'ndan 16.12.2016 tarih ve 346 sayil karar ile onay alindi.

\section{ÇIKAR ÇATIŞMASI}

Yazarlar bu makale ile ilgili herhangi bir c1kar çatıșması bildirmemișlerdir.

\section{YAZAR KATKISI}

Anafikir/Planlama: Tüm yazarlar

Analiz/Yorum: SA

Veri sağlama: NÖ, NS

Yazım: NÖ

Gözden Geçirme ve Düzeltme: Tüm yazarlar

Onaylama: Tüm yazarlar 


\section{KAYNAKLAR}

1. Winn WJ, Allen S, Janda W, Koneman E, Procop G, Schreckenberger $P$, et al. The anaerobic bacteria. In: Koneman EW (ed). Koneman's Color Atlas and Textbook of Diagnostic Microbiology. $7^{\text {th }}$ ed. Baltimore: Lippincott Williams \& Wilkins, 2017:984-1074.

2. Jeverica $S$, Kolenc U, Mueller-Premru M, Papst L. Evaluation of the routine antimicrobial susceptibility testing results of clinically significant anaerobic bacteria in a Slovenian tertiary-care hospital in 2015. Anaerobe 2017;47:64-9.

3. Nagy E, Becker S, Kostrzewa M, Barta N, Urban E. The value of MALDI-TOF MS for the identification of clinically relevant anaerobic bacteria in routine laboratories. J Med Microbiol 2012;61:1393-400.

4. Veloo ACM, Erhard $M$, Welker $M$, Welling GW, Degener JE. Identification of gram-positive anaerobic cocci by MALDI-TOF mass spectrometry. Syst Appl Microbiol 2011;34:58-62.

5. Barba MJ, Fernandez $A$, Oviano $M$, Fernandez $B$, Velasco D, Bou G. Evaluation of MALDI-TOF mass spectrometry for identification of anaerobic bacteria. Anaerobe 2014;30:126-8.

6. Ülger Toprak N, Alida CMV, Urban E, Wybo I, Justesen US, Jean-Pierre $H$, et al. Performance of mass spectrometric identification of clinical Prevotella species using the VITEK MS system: a prospective multi-center study. Anaerobe 2018;54:205-9.

7. Clinical and Laboratory Standards Institute (CLSI). M100 Performance Standards for Antimicrobial Susceptibility Testing $28^{\text {th }}$ Edition; 2018.

8. EUCAST. European Committee on Antimicrobial Susceptibility Testing Breakpoint Tables for Interpretation of MICs and Zone Diameters- Version 8.0.; 2018.

9. Clinical and Laboratory Standards Institute. M07-A10 Methods for Dilution Antimicrobial Susceptibility Tests for Bacteria That Grow Aerobically; Approved Standard-Tenth Edition.; 2015.

10. Karlowsky JA, Walkty AJ, Adam HJ, Baxter MR, Hoban DJ, Zhanel GG. Prevalence of antimicrobial resistance among clinical isolates of Bacteroides fragilis group in Canada in 2010-2011: CANWARD surveillance study. Antimicrob Agents Chemother 2012;56:1247-52.

11. Nagy E, Urban E, Nord CE. Antimicrobial susceptibility of Bacteroides fragilis group isolates in Europe: 20 years of experience. Clin Microbiol Infect 2011;17:371-9.

12. Brook I. Antibiotic resistance of anaerobic bacteria. In: Mayers DL, Lerner SA, Quelette M, Sobel JD (eds). Antimicrobial Drug Resistance. Totowa, NJ: Humana Press, 2009:873-99.

13. Gajdacs $M$, Spengler $G$, Urban E. Identification and antimicrobial susceptibility testing of anaerobic bacteria: $R u$ bik's cube of clinical microbiology? Antibiot 2017;6:25.

14. Ülger Toprak N, Veloo ACM, Urban E, Wybo I, Justesen US, Jean-Pierre $H$, et al. A multicenter survey of antimicrobial susceptibility of Prevotella species as determined by Etest methodology. Anaerobe 2018;52:9-15.
15. Liu CY, Huang YT, Liao CH, Yen LC, Lin HY, Hsueh PR. Increasing trends in antimicrobial resistance among clinically important anaerobes and Bacteroides fragilis isolates causing nosocomial infections: emerging resistance to carbapenems. Antimicrob Agents Chemother 2008;52:3161-8.

16. Urban E, Soki J, Brazier JS, Nagy E, Duerden BI. Prevalence and characterization of nim genes of Bacteroides spp. isolated in Hungary. Anaerobe 2002;8:175-9.

17. Holden J, Hall GS. Collection, transport, and processing of clinical specimens. In: Garcia LS (ed). Clinical Microbiology Procedures Handbook. 3rd ed. Washington, DC: American Society for Microbiology, 2010:4.2.1.

18. Mangels JI. Incubation techniques for anaerobes. In: Garcia LS (ed). Clinical Microbiology Procedures Handbook. 3rd ed. Washington, DC: American Society for Microbiology, 2010:4.5.1.

19. Summanen P. Rapid disk spot tests, and other rapid or primary methods, anaerobes. In: Garcia LS (ed). Clinical Microbiology Procedures Handbook. 3rd ed. Washington, DC: American Society for Microbiology, 2010:4.6.1.1.

20. MALDI Biotyper CA System-Clinical Application for Identification of Microorganisms. Billerica, MA; 2014.

21. Clinical and Laboratory Standards Institute. M56-A Principles and Procedures for Detection of Anaerobes in Clinical Specimens; Approved Guideline, 2014.

22. Hedberg M, Nord CE. Antimicrobial susceptibility of Bacteroides fragilis group isolates in Europe. Clin Microbiol Infect 2003;9:475-88.

23. Ercis S, Tunçkanat F, Hasçelik G. Anaerobik enfeksiyon şüpheli hastalardan izole edilen anaerop bakteriler. Mikrobiyol Bul 2005;39:447-54.

24. Keşli R, Çelebi S. Çeşitli klinik örneklerden izole edilerek tanımlanan anaerob bakteriler ve E-test yöntemi ile antibiyotik duyarlılıklarının belirlenmesi. Türk Mikrobiyoloji Cemiy Derg 2010;40:87-96.

25. Bozkurt H, Güdücüoğlu H, Bayram Y, Gülmez S, Kutulay $N$, Bozkurt $N$, et al. Klinik örneklerden izole edilen anaerob bakteriler ve antibiyotik duyarlılıkları. Van Tıp Derg 2004;11:85-91.

26. Demir C, Keşli R. Çeşitli klinik örneklerden izole edilen gram-negatif anaerob basillerin tiplendirilmesi ve antibiyotik direnç profillerinin E-test yöntemi ile belirlenmesi. Mikrobiyol Bul 2018;52:72-9.

27. Doğan M, Baysal B. Çeşitli klinik örneklerden izole edilen anaerop bakterilerin tanımlanması ve antibiyotik duyarlılıklarının belirlenmesi. Mikrobiyol Bul 2010;44:211-9.

28. Bilge Uysal E, Çelik C, Alan Ç, Kaya H, Gözel MG, Bakıcı MZ. Klinik örneklerden izole edilen anaerobik bakteriler: yedi yılIık değerlendirme. Cumhuriyet Tıp Derg 2014;36:327-31.

29. Argun Türkkan A, Kiremitçi A. Klinik örneklerden soyutlanan anaerop bakterilerin tanımlanması ve E-test yöntemi ile antibiyotik duyarlılıklarının belirlenmesi. 2008. 
30. Demirci M, Gemicioglu B, Saribas S, Taner Z, Mamal-Torun $M$, Karatoka $B$, et al. A retrospective analysis of anaerobic bacteria isolated in 236 cases of pleural empyema and their prevalance of antimicrobial resistance in Turkey. Clin Lab 2018;64:1269-77.

31. Shilnikova II, Dmitrieva NV. Evaluation of antibiotic susceptibility of gram-positive anaerobic cocci isolated from cancer patients of the NN Blokhin Russian Cancer Research Center. J Pathog 2015;2015:648134.

32. Rodloff $A C$, Dowzicky MJ. In vitro activity of tigecycline and comparators against a European collection of anaerobes collected as part of the Tigecycline Evaluation and Surveillance Trial (T.E.S.T.) 2010-2016. Anaerobe 2018;51:7888 .

33. Wybo I, Van den Bossche D, Soetens O, Vekens E, Vandoorslaer $K$, Claeys $G$, et al. Fourth Belgian multicentre survey of antibiotic susceptibility of anaerobic bacteria. J Antimicrob Chemother 2014;69:155-61.
34. Ülger Toprak N, Uzunkaya OD, Soki J, Soyletir G. Susceptibility profiles and resistance genes for carbapenems (cfiA) and metronidazole (nim) among Bacteroides species in a Turkish University Hospital. Anaerobe 2012;18:169-71.

\section{Yazıșma Adresi/Address for Correspondence}

Uzm. Dr. Nida ÖZCAN

Dicle Üniversitesi Tıp Fakültesi,

Tıbbi Mikrobiyoloji Anabilim Dalı,

Diyarbakır-Türkiye

E-posta: nida.ozcan@dicle.edu.tr 